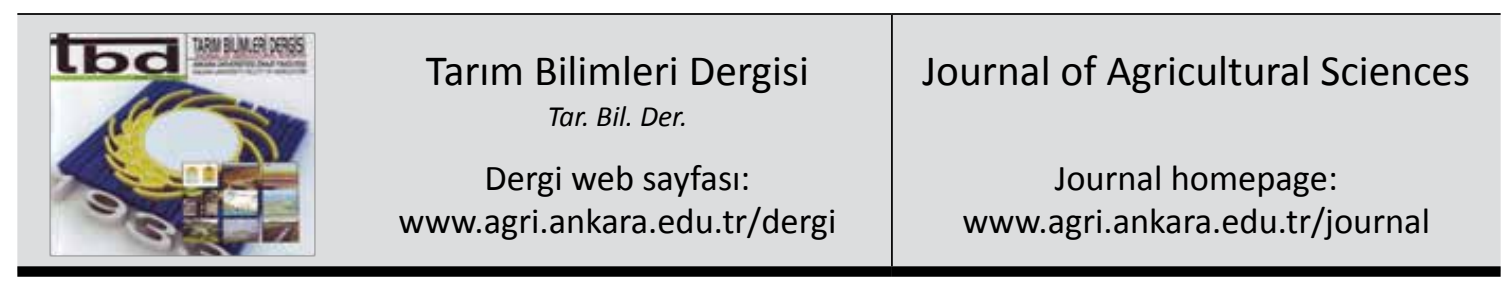

\title{
Hamsi Balığı (Engraulis encrasicolus) Dönerinin Soğuk Depolama Sırasındaki Kalite Değişimleri
}

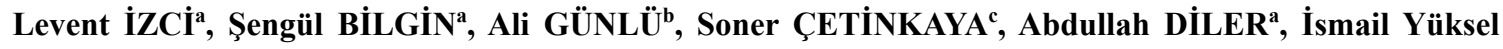 \\ GENÇ $^{\mathrm{a}}$, Yıldız BOLAT \\ ${ }^{a}$ Süleyman Demirel Üniversitesi, Eğirdir Su Ürünleri Fakültesi, Su Ürünleri Avlama ve İşleme Teknolojisi Anabilim Dall, Isparta, TÜRKIYYE

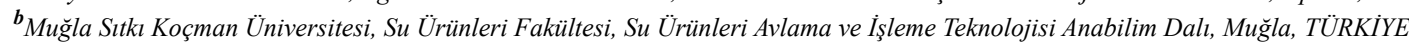 \\ ${ }^{c}$ Gıda Tarım ve Hayvancılık Bakanlığı, Su Ürünleri Araştırma Enstitüsü Müdürlüğü, Isparta, TÜRKIYE
}

\section{ESER BÍLGİSI}

Araştırma Makalesi

DOI: $10.1501 /$ Tarimbil 0000001394

Sorumlu Yazar: Levent İZCI, E-posta: leventizci@sdu.edu.tr, Tel: +90 (246) 2118681

Geliş Tarihi: 12 Ocak 2014, Düzeltmelerin Gelişi: 17 Mart 2015, Kabul: 17 Mart 2015

\section{ÖZET}

$\mathrm{Bu}$ çalışmada, hamsi balığından döner yapılması ve kalite özelliklerinin belirlenmesi amaçlanmıştır. Hamsi balığı dönerinde $\% 52.17 \mathrm{su}, \% 24.79$ ham protein, \% 18.62 ham yağ ve \% 4.28 oranında ham kül saptanmıştır. Muhafaza süresinin sonunda hamsi döner örneklerinde doymuş yağ asitleri (DYA) içerisinde $\mathrm{C}_{16: 0}$, tekli doymamış yağ asitleri (TDYA) içerisinde $\mathrm{C}_{18: 1 \mathrm{n}-9}$ ve çoklu doymamış yağ asitleri (ÇDYA) içerisinde ise $\mathrm{C}_{22: 6 \mathrm{n}-3}$ ün en yüksek orana sahip olduğu tespit edilmiştir. Genel olarak, hamsi dönerler örneklerinde $\sum \mathrm{n} 6 / \sum \mathrm{n} 3$ oranında ve DHA/EPA (dekosahegzaenoik asit, $\mathrm{C}_{22: 6 \mathrm{n}-3}$ /eikosapentaenoik asit, $\mathrm{C}_{20: 5 \mathrm{n}-3}$ ) oranında önemsiz bir değişim tespit edilmiştir $(\mathrm{P}>0.05)$. Depolama sonunda hamsi döner örneklerinde $\mathrm{pH}$, tiyobarbitürik asit (TBA), toplam uçucu bazik azot (TVB-N) ve trimetilamin azot (TMA-N) değerleri sırasıyla $6.25,3.53 \mathrm{mg}$ MDA kg-1, $34.03 \mathrm{mg} 100 \mathrm{~g}^{-1}$ ve $5.25 \mathrm{mg} 100 \mathrm{~g}^{-1}$ olarak saptanmıştır. Hamsi döner örneklerinde toplam mezofilik aerob bakteri (TMAB) ve toplam psikrofilik aerob bakteri (TPAB) sayısı depolama ile birlikte artarak muhafaza süresi sonunda sırasıyla $4.82 \operatorname{logkob~g}^{-1}$ ve $4.39 \operatorname{logkob~g} \mathrm{g}^{-1}$ değerlerine ulaşmıştır. Maya-küf ve koliforma ise rastlanılmamıştır. Duyusal analiz sonuçlarından panelistlerce hamsi dönerin beğenildiği anlaşılmaktadır. Bu çalışmada, hamsiden üretilen döner örneklerinin 63.günde bozulduğu belirlenmiştir.

Anahtar Kelimeler: Hamsi; Balık döner; Besin bileşenleri; Yağ asidi; Raf ömrü

\section{Quality Changes of Anchovy (Engraulis encrasicolus) Döner During Cold Storage}

\author{
ARTICLE INFO \\ Research Article \\ Corresponding Author: Levent İZCI, E-mail: leventizci@sdu.edu.tr, Tel: +90 (246) 2118681 \\ Received: 12 January 2014, Received in Revised Form: 17 March 2015, Accepted: 17 March 2015
}

\section{ABSTRACT}

In this study, döner producing from anchovy and determination of quality properties of anchovy döner were aimed. Proximate composition of anchovy döner have been determined as $52.17 \%$ moisture, $24.79 \%$ crude protein, $18.62 \%$ 
crude fat and $4.28 \%$ crude ash. $\mathrm{C}_{16: 0}$ among saturated fatty acids (SFA) and $\mathrm{C}_{18: 1 \mathrm{n}-9}$ among monounsaturated fatty acids (MUFA) and $\mathrm{C}_{22: 6 \mathrm{n}-3}$ among polyunsaturated fatty acids (PUFA) were determined the highest rates at the end of storage. Generally, $\sum \mathrm{n} 6 / \sum \mathrm{n} 3$ and DHA/EPA (decosahexaenoic acid, $\mathrm{C}_{22: 6 \mathrm{n}-3} /$ eicosapentaenoic acid, $\mathrm{C}_{20: 5 \mathrm{n}-3}$ ) rates of anchovy döner were showed insignificant $(\mathrm{P}>0.05)$ changes at the end of storage. At the end of storage period $\mathrm{pH}$, thiobarbituric acid (TBA), total volatile basic nitrogen (TVB-N) and trimethylamine nitrogen (TMA-N) values of anchovy döner were found

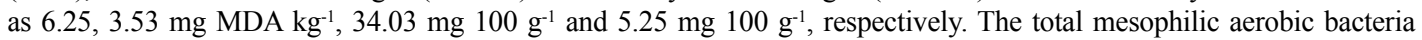
(TMAB) and total psychrophilic aerobic bacteria (TPAB) counts of anchovy döner were increased during storage and reached to $4.82 \operatorname{logcfu~g}^{-1}$ and $4.39 \operatorname{logcfu~g}^{-1}$, respectively. Yeast-mould and coliform bacteria in anchovy döner were not detected. It was found that the anchovy döner was enjoyed by panelists according to results of sensory analysis. In this study, the results showed that deterioration of the döner samples produced from anchovy were determined on $63^{\text {rd }}$ days.

Keywords: Anchovy; Fish döner; Nutritional components; Fatty acid; Shelf life

(C) Ankara Üniversitesi Ziraat Fakültesi

\section{Giriş}

Su ürünleri besleyici değerinin oldukça yüksek olması bakımından insanlık için önemli bir besin kaynağıdır. Geçmişte genellikle taze olarak tüketilen su ürünleri günümüzde gelişen teknolojiyle birlikte farklı şekillerde işlenebilmekte ve insanlar için seçenekli besin grupları haline dönüştürülebilmektedir. $\mathrm{Su}$ ürünlerinin gelecekte insanlar için en önemli hayvansal protein kaynağı olacağı düşünülmektedir. Günümüz hızlı yaşam temposu içerisinde beslenme alışkanlıklarındaki değişimler göz önünde bulundurulduğunda avcılık ve yetiştiricilik yoluyla elde edilen ürünlerin damak tadına yenilikler sunması için gerçekleştirilecek çalışmalara önem verilmelidir. Deniz ve içsu kaynaklarından sağlanan su ürünleri, içerdiği proteinler, çoklu doymamış yağ asitleri, mineral madde ve vitaminler sayesinde beslenmemiz açısından önemli bir yere sahiptir (Turan et al 2006). Alternatif protein kaynakları ile kıyaslandığında, su ürünlerinin daha ekonomik besin kaynağı olduğu ve değişik yöntemlerle işlenerek depolandığında da zaman içinde protein değerini yitirmeden tüketilme özelliğine sahip olduğu da bilinmektedir (Kolsarıcı \& Özkaya 1998). Diğer besinlerde bulunmayan ancak insan beslenmesinde önemli rolü olan Eikosapentaenoik asit (EPA) ve Dekosahegzaenoik (DHA) asit gibi çoklu doymamış yağ asitlerini bulundurması su ürünlerini daha özel bir besin haline getiren unsurlardan biridir (Kaya et al 2004; Turan et al 2006).Yapılan araştırmalar, insanların karşılaştığı birçok hastalığa besin maddelerinin ve beslenme alışkanlıklarının neden olduğunu ortaya koymaktadır. $\mathrm{Bu}$ nedenle daha sağlıklı olan doymamış yağ asitleri bakımından zengin gidaların tüketilmesi önerilmektedir (Kaya et al 2004). Birleşik Krallık Sağlık Departmanınca ideal $\mathrm{n} 6 / \mathrm{n} 3$ oran 1 maksimum 4 olarak tavsiye edilmiş, n6/n3 oranının maksimum değerden daha fazla olmasının sağlığa zararlı olduğu ve kalp-damar hastalıklarını da artırıcı olabileceği ifade edilmiştir (Moreira et al 2001). Hamsinin balık köftesi (Varlık et al 2000), marinat (Olgunoğlu 2007), dumanlama (Ayas 2006), surimi (Kaba 2006), hamsi keki (İnanlı et al 2011) ve hamsikuşu (Köse et al 2001) gibi ürünleri üzerine farklı araştırıcıların çalışmaları bulunmakla birlikte hamsiden döner yapımına ilişkin her hangi bir çalışmaya rastlanılmamıştır.

Toplam üretimimiz içerisinde 179615.2 ton ile ülkemiz su ürünleri üretiminin yaklaşık \% 30'nu oluşturan hamsinin 76190.4 tonluk önemli bir kısmı balık unu ve yağı fabrikalarında yan ürün olarak değerlendirilmektedir (TÜİK 2013). Bu çalışma ile hamsiden yeni bir damak tadı oluşturarak tüketici için albenisi-beğenisi yüksek ve çağımızın 1sıtye cinsi beslenme alışkanlıklarına uygun bir ürün grubu oluşturulmasının yanı sıra kalite özelliklerinin belirlenmesi hedeflenmiştir. Ayrıca bu şekilde katma değerinin daha da artırılması amaçlanmıştır.

\section{Materyal ve Yöntem}

Çalışmada, perakende satış noktasından temin edilen hamsi balığı (Engraulis encrasicolus) buzlu strafor kutularda 1 saat içerisinde laboratuvara getirilmiştir. İlk olarak baş, iç organ ve omurga 
çıkartılarak filetoları elde edilmiş, şebeke suyu ile yıkanarak temizlenmiş, suyu sızdırılmış ve döner yapımı için hazır hale getirilmiştir. Döner yapımında kullanılacak katkıların oranları toplam balık fileto ağırlığı dikkate alınarak \% olarak hesaplanmıştır. Buna göre ağzı kapaklı şeffaf temiz plastik bir kap içerisinde bulunan temizlenmiş ve suyu sızdırılmış hamsi filetolarının üzerine katkı maddeleri, toplam fileto ağırlığının \% 2.00'si oranında tuz, \% 0.44 'ü oranında karabiber ve \% 7.00'si oranında soğan suyu olacak şekilde ilave edilerek iyice karıştırılmıştır ve aroma oluşumu için $4 \pm 1{ }^{\circ} \mathrm{C}$ 'de 120 dakika süre ile marine edilmiştir. Bu sürenin sonunda filetolar döner çubuğunun altında bulunan sirküler tablanın üzerine dizilmiştir. Marinasyon ve dizme işlemi sonrası pişirme işlemine geçilmiştir. Döner çubuğunun bağlı olduğu ve et bloğunun otomatik dönmesini sağlayan motor aparatı ile eşit pişirme sağlanmaya çalışılmıştır. Pişen yüzeyler döner bıçağı ile kesilmiştir. Kesilen parçalar döner tepsisinde oda sıcaklığına ulaşır ulaşmaz ağzı kapaklı plastik şeffaf kaplarda homojen bir karışım sağlanarak pişirme işleminin sonuna kadar $4 \pm 1{ }^{\circ} \mathrm{C}$ 'de muhafaza edilmiştir. Daha sonra $100 \pm 10 \mathrm{~g}$ olacak şekilde döner örnekleri vakum paketlenerek $4 \pm 1{ }^{\circ} \mathrm{C}$ 'de 63 gün süreyle depolanmıştır. Döner örneklerinden muhafaza süresince $1,7,14,21,28,35,42,49,56$ ve 63. günlerde analizler gerçekleştirilmiştir.

\subsection{Kimyasal analizler}

Tüm örneklerde su, ham protein (AOAC 2000), ham yağ (Lovell 1975) ve ham kül (Lovell 1981) analizleri yapılmıştır. Yağ asidi analizi; örneklerden yağ çıkarma işlemi yapılmış (Bligh \& Dyer 1959) ve sonrasında metilleştirme işlemi (Ichihara et al 1996) küçük bir modifikasyon ile gerçekleştirilmiştir. Gaz Kromotografisi (GC) Şartları; Yağ asitleri GC Clarous 500 cihazı (Perkin-Elmer, USA), alev iyonizasyon dedektörü ve silika kapiler kolon (30 m x 0.32 mm ID, $0.25 \mu \mathrm{m}$ BP20 0.25 UM; USA) kullanılarak analiz edilmiştir. Enjektör ve dedektör sıcaklıkları sırası ile önce $220^{\circ} \mathrm{C}$ 'ye sonra $280^{\circ} \mathrm{C}$ 'ye ayarlanmıştır. $\mathrm{Bu}$ esnada firın sıcaklığı 5 dakika $140{ }^{\circ} \mathrm{C}$ 'de tutulmuştur. Sonrasında her dakika 4 ${ }^{\circ} \mathrm{C}$ arttırılarak $200{ }^{\circ} \mathrm{C}$ 'ye kadar, $200{ }^{\circ} \mathrm{C}$ 'den 220 ${ }^{\circ} \mathrm{C}$ 'ye de her dakika $1{ }^{\circ} \mathrm{C}$ artırılarak getirilmiştir.
Split 1:50 oranında kullanılmıştır. Yağ asitleri standart 37 bileşenden oluşan FAME karışımının gelme zamanlarına bağlı olarak karşılaştııılmasıyla tanımlanmıştır. GC analiz sonuçları \pm standart hataları ile birlikte $\%$ olarak ifade edilmiştir.

Ayrıca, pH (Varlık et al 2007), tiyobarbitürik asit (TBA, mg MDA kg-1) (Erkan \& Özden 2008), toplam uçucu bazik azot (TVB-N, mg $100 \mathrm{~g}^{-1}$ ) (Nicholas 2003), trimetilamin azot (TMA-N, mg $100 \mathrm{~g}^{-1}$ ) (AOAC 1998) analizleri yapılmıştır.

\subsection{Mikrobiyolojik analizler}

Bütün örneklerde toplam mezofilik aerob bakteri (TMAB, logkob $\mathrm{g}^{-1}$ ) ve toplam psikrofilik aerob bakteri (TPAB, logkob g $\mathrm{g}^{-1}$ ) sayısı ile koliform ve maya-küf mikroorgnizma sayılarını belirlemek için mikrobiyolojik analizler yapılmıştır (Harrigan \& McCance 1976; ICMSF 1978; Refai 1979; Arslan et al 1997).

\subsection{Duyusal özelliklerin analizi}

Duyusal özelliklerin değerlendirilmesinde renk, koku, lezzet, tekstür ve genel beğeni özelliklerinden yararlanılmıştır (Taşkaya et al 2003; Tokur et al 2006; Kenar 2009). Fakültemiz personeli ve öğrencileri arasından seçilmiş eğitimli 12 panelistten ssıtılarak sunulmuş döner örneklerinin duyusal özelliklerini 1-9 puan arasında değerlendirmeleri istenmiştir. Değerlendirmede 9 tamamen tazeliği, $\leq 3$ ise bozulmuşluğu göstermektedir. Duyusal özelliklerin belirlenmesine yönelik analizlere muhafaza süresince devam edilmiştir.

\subsection{Istatistiksel analiz}

Çalışmada elde edilen veriler, SPSS 9.0 istatistik paket programı ile varyans analizine (one-way ANOVA) tabi tutulup, önemli varyans kaynaklarına ait ortalamalar Duncan Çoklu Karşılaştırma Testi ile $\mathrm{P}<0.05$ güven aralığında karşılaştırılmıştır.

\section{Bulgular ve Tartışma}

Çiğ hamsi (Ç), marine hamsi (M) ve hamsi döner (D) örneklerinin su, ham protein, ham yağ ve ham kül oranlarını belirlemeye yönelik besin bileşen analizleri yapılmıştır (Çizelge 1). Özellikle pişirme 
işlemiyle birlikte ürün su içeriğinin önemli $(\mathrm{P}<0.05)$ miktarda azalmasına bağlı olarak ham protein ve ham yağ içeriğinde nispi olarak $(\mathrm{P}<0.05)$, ham kül miktarlarında ise yine su içeriğinin azalmasına ve kullanılan katkılara bağlı olarak son üründe $(\mathrm{P}<0.05)$ artış belirlenmiştir. Hamsinin aylara göre su içeriğinin belirlendiği bir araștırmada su içeriğinin \% 64.93 ile \% 74.32 aralığında olduğu (Öksüz \& Özyılmaz 2010), benzer bir çalışmada da \% 66.0 ile \% 77.0 (Gökoğlu et al 1999) olarak bulunduğu, diğer çalışmalarda \% 66.95 (Kocatepe \& Turan 2012), \% 69.76 (Özden 2005), \% 68.21 (İnanlı et al 2010) ve \% 61.45 ile \% 77.10 (Karaçam \& Düzgüneş 1988) olarak tespit edilmiştir. Alabalık, orkinos ve somon türlerinin döner olarak değerlendirildiği çalışmada su içeriğinin başlangıca göre düştügü belirlenmiştir (Şimşek 2011). Hamsi üzerine yapılan farklı araştırmalarda, protein oran $\% 16.31$ (Kocatepe \& Turan 2012), \% 15.06 ile \% 18.91 (Karaçam \& Düzgüneş 1988), \% 19.56 (Ayas 2006), \% 16.94-\% 17.36 (Kaya \& Turan 2010), \% 19.07 (İnanlı et al 2010), \% 18.02 (Özden 2005) olarak belirlenmiştir. Farklı türlerden döner yapılan örnek gruplarında protein oranında artış saptanmışırır (Şimşek 2011). Hamside yağ oranını \% 4.72 (Ayas 2006), \% 5.1 ile \% 13.6 (Gökoğlu et al 1999) \% 6.49\% 16.32 (Öksüz \& Özyılmaz 2010), \% 10.04 (İnanlı et al 2010) olarak tespit edilmiştir. Alabalık, orkinos ve somon pişmiş döner örneklerinde yağ miktarında başlangıca göre artış saptanmıştır (Şimşek 2011). Yapılan çalışmalara göre, hamside kül miktarı \% 1.39 (Ayas 2006), \% 1.35 ile \% 1.68 (Öksüz \& Özyılmaz 2010), \% 1.03 (Kocatepe \& Turan 2012), \% 1.62 (Özden 2005) olarak belirlenmiş olup elde edilen bu sonuçlar bulgularımızla paralellik göstermektedir.

\section{Çizelge 1- Çiğ, marine hamsi ve hamsi döner besin bileșenleri $(\%)^{*},(\mathrm{x} \pm \mathbf{S H})^{* *}$}

Table 1- Nutritional compenents of raw, marinated anchovy and anchovy döner $(\%)^{*},(x \pm S E)^{* *}$

\begin{tabular}{llll}
\hline \multicolumn{1}{c}{ Su } & Ham protein & Ham yă & Ham kül \\
\hline Ç $67.91 \pm 0.29^{\mathrm{a}}$ & $17.68 \pm 0.08^{\mathrm{b}}$ & $12.80 \pm 0.86^{\mathrm{b}}$ & $1.27 \pm 0.05^{\mathrm{c}}$ \\
M 71.05 $2.13^{\mathrm{a}}$ & $15.78 \pm 0.16^{\mathrm{c}}$ & $10.38 \pm 0.75^{\mathrm{c}}$ & $2.38 \pm 0.06^{\mathrm{b}}$ \\
D $52.17 \pm 0.41^{\mathrm{b}}$ & $24.79 \pm 0.11^{\mathrm{a}}$ & $18.62 \pm 0.29^{\mathrm{a}}$ & $4.28 \pm 0.04^{\mathrm{a}}$ \\
\hline
\end{tabular}

*, aynı sütunda farklı harfler bulunduran değerler arasında istatistiki fark önemlidir $(\mathrm{P}<0.05)$; ${ }^{* *}$, ortalama \pm standart hata; $\mathrm{C}$, çiğ hamsi; M, marine hamsi; D: hamsi döner
Yağ asitleri analiz sonuçlarından da anlaşılacağı gibi çoklu doymamış yağ asitlerinden $\mathrm{C}_{22: 6}$ n-3 ve $\mathrm{C}_{20: 5 n-3}$ önemli miktarlarda belirlenmiştir (Çizelge 2). Analizi yapılan tüm örnek grupları içerisinde en fazla tespit edilen yağ asidi çoklu doymamış yağ asitlerinden DHA olmuştur. Ham maddeyi oluşturan çiğ hamside \% 20.00 olarak tespit edilen DHA, marinasyon işlemiyle \% 19.10'a depolamanın başlangicinda (1. gün) döner örneklerinde $\%$ 18.76'ya azalmıştır ( $>>0.05)$. EPA'da ise çiğ hamside \% 10.66 olarak tespit edilen değer marinasyon işlemiyle \% 9.94'e azalmış $(\mathrm{P}<0.05)$ depolamanın başlangıcında döner örneklerinde $\%$ 10.01'e artmıştır ( $\mathrm{P}>0.05)$. Çiğ hamside $\sum \mathrm{DYA}$, $\sum$ TDYA ve $\sum$ ÇDYA sirasiyla $\% 31.40, \% 20.16$ ve $\% 36.68$ olarak, marine hamside ise sirasiyla $\% 29.98, \% 22.03$ ve $\% 35.34$ olarak, 1. gün döner örneklerinde ise sirasıly \% 29.34, \% 22.70 ve $\% 35.00$ olarak saptanmıştır. Hamsi döner örneklerinde depolama süresince $\sum$ DYA, $\sum$ TDYA ve $\sum$ ÇDYA küçük artış ve azalışlar tespit edilmiş olup depolamanın 1. günü ile depolamanın son günü (63. gün) $\sum$ DYA'deki değişim önemli $(\mathrm{P}<0.05)$ bulunurken, $\sum$ TDYA ve $\sum$ ÇDYA için önemsiz $(\mathrm{P}>0.05)$ bulunmuştur. Depolamanın başlangıcında ve sonunda döner örneklerinin $\sum \mathrm{n} 6 / \sum \mathrm{n} 3$ oran arasında önemli bir değişim gözlenmemiş̧ir (P>0.05) (Çizelge 2). Hamside $\sum D Y A \% 33.40$ $\% 37.91, \sum$ TDYA $\% 25.91-\% 31.51, \sum$ ÇDYA\%34.00\%36.18(Öksüz\& Özyılmaz 2010) olarakbulunurken, başka bir araştırmada DDYA \% 35.07, ¿TDYA $\% 19.50$ ve $\sum$ ÇDYA \% 32.43, DHA/EPA oranı 1.45 olarak saptanmıştır (Kocatepe \& Turan 2012), Tufan et al (2011) aynı tür ile yaptıkları çalışmada EDYA \% $\quad 29.81-\% \quad 37.58$, $\sum$ TDYA $\%$ 18.82$\% 22.49$ ve $\sum$ ÇDYA \% 31.95-\% 38.52 arasında, $\sum$ ÇDYA/ $\sum$ DYA $0.86-1.29$ ve $\sum \mathrm{n} 6 / \sum \mathrm{n} 3$ oranını ise 0.10-0.22 arasında tespit etmişlerdir. Zlatanos \& Laskaridis (2007) hamsilerde önemli doymamış yağ asitlerinden $\mathrm{C}_{22: 6 \mathrm{n}-3}$ ' $\ddot{\mathrm{u}}$ en düşük oranda \% 12.23 Şubat ayında, en yüksek oranda ise \% 32.46'lık oranla Haziran ayında belirlemiştir. Hamsi üzerine yapılan bir çalışmada yağ asidi kompozisyonunda DYA içinde $\mathrm{C}_{16: 0,}$, TDYA içinde $\mathrm{C}_{\text {18:1 n-9 } 9}$ ve ÇDYA içinde de $\mathrm{C}_{22: 6 \text { n-3 }}$ 'ün en yüksek oranda olduğunu tespit edilmiştir (Tanakol et al 1999). Bu sonuçlar 


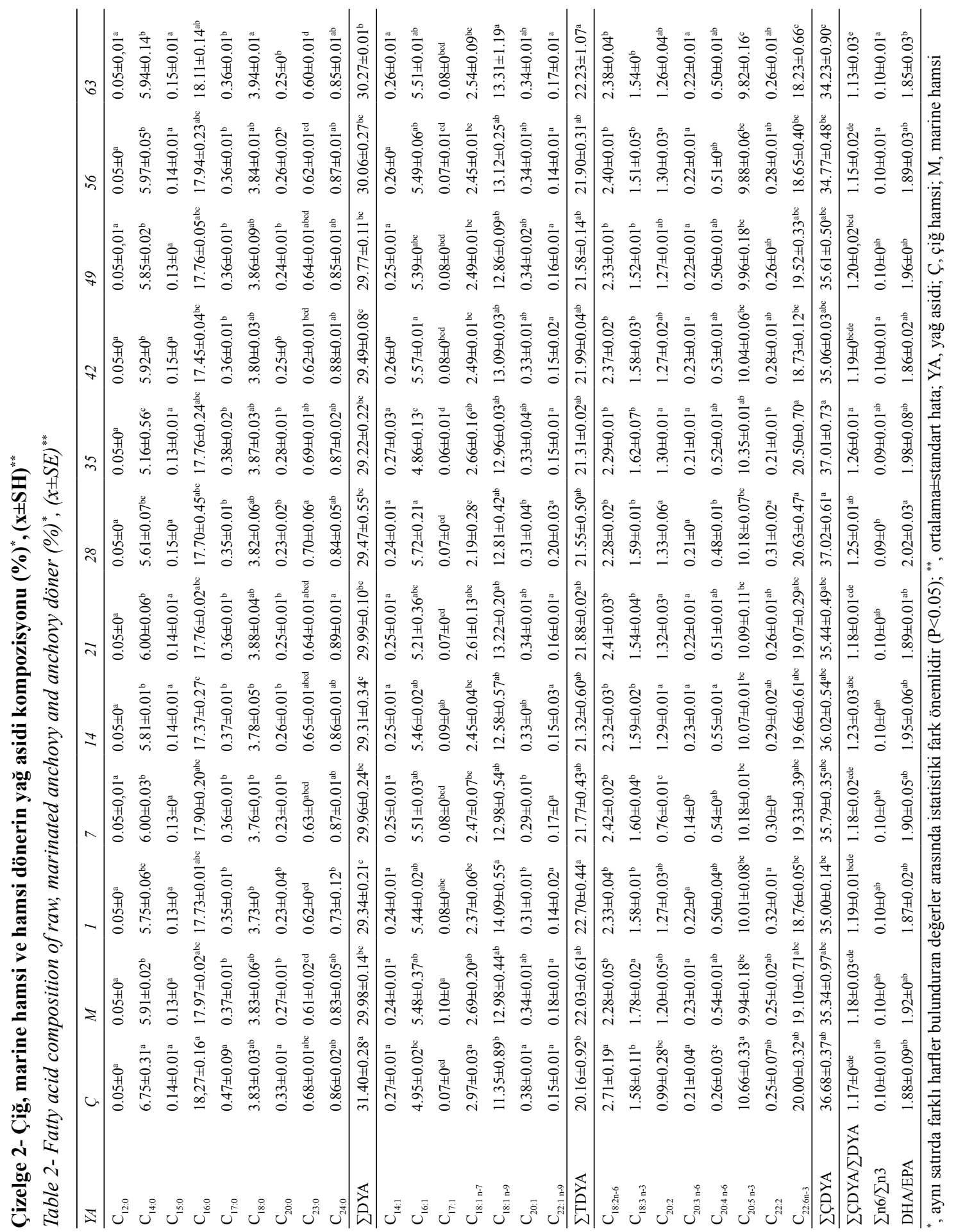


çalışmamızı genel olarak destekler niteliktedir. Ortaya çıkan farklılıkların hammadde ve çalışma koşullarından kaynaklanabileceği düşünülmektedir.

Çalışmamızda çiğ hamsi örneklerinde 6.61 olarak tespit edilen $\mathrm{pH}$ değeri marinasyon işlemiyle birlikte azalmış $(\mathrm{P}<0.05)$ depolamanın 1. gününde ise artmıştır $(\mathrm{P}<0.05)$ (Çizelge 3$)$. $\mathrm{Bir}$ çalışmada, orkinos dışında alabalık ve somon döner örneklerinde 1. gün $\mathrm{pH}$ değerinde çiğ balık etine göre önemli $(\mathrm{P}<0.05)$ değişim bulunmuştur (Şimşek 2011). Balık etlerinde TBA değerinin 3-4 mg MDA kg-1' 1 üzerinde olmasının kalite kaybının göstergesi olduğu belirtilmiştir (Köse et al 2001). Varlik et al (1993) ve Cadun et al (2005) tüketilebilirlik değerinin 7-8 mg MDA kg-1 arasında olduğunu bildirmiştir. Araştırmamızda hamsi döner örneklerinin TBA değeri muhafaza süresince genellikle artış eğiliminde olmuştur (Çizelge 3). Yapılan bir araştırmada, tuzlanmış ve tuzlanmamış hamsiden elde edilen hamsikuşu, pişmiş ve pişmemiş olarak depolamış ve bu süre içinde TBA değerinin düzensiz bir değişim gösterdiği tespit edilmiştir (Köse et al 2001). Alabalık, orkinos ve somon döner örneklerinde TBARS değerinin depolamaya bağlı olarak arttığ saptanmıştır (Şimşek 2011). TVB-N su ürünlerinin bozulmasının belirlenmesinde yaygin kullanılan biyokimyasal metotlardan biridir (Ruiz-Capillas \& Moral 2001). Huss (1988) ve Köse \& Erdem (2004) TVB-N için kabul edilebilir limit değerini 30-35 mg $100 \mathrm{~g}^{-1}$, Varlık et al (1993) ve Akkuş et al (2004) $35 \mathrm{mg} 100 \mathrm{~g}^{-1}$ olarak bildirmişlerdir. Çalışmamızda hamsi dönerde TVB-N değeri depolamanın sonunda (63. gün) $34.03 \mathrm{mg} 100 \mathrm{~g}^{-1}$ 'a ulaşmıştır (Çizelge 3). Tuzlanmış ve tuzlanmamış hamsilerden yapılan hamsikuşunun pişirilerek $-18{ }^{\circ} \mathrm{C}$ 'de 150 günlük depolanması sonunda TVB-N değerleri sirasiyla

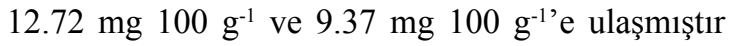
(Köse et al 2001). Buzdolabı koşullarında depolanan hamsi balığının TVB-N değerinin depolamanın sonunda (5. gün) artarak $35.4 \mathrm{mg} 100 \mathrm{~g} \mathrm{~g}^{-1}-38.8 \mathrm{mg}$ $100 \mathrm{~g}^{-1}$ 'a ulaştığ 1 bildirilmiştir (Köse \& Erdem 2004). Varlık et al (1993) TMA-N sinır değerini 8

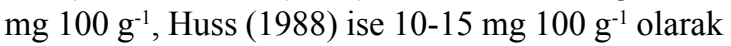
belirtmiştir. Araştırmamızda TMA-N çiğ hamside

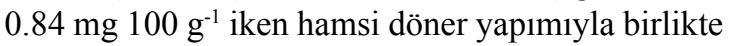
artmış ve depolamanın sonunda $5.25 \mathrm{mg} 100 \mathrm{~g}^{-1}$ 'a ulaşmışırır (Çizelge 3). Hamsi keki çalışmasında kekin pişirilmesi ile $3.14 \mathrm{mg} 100 \mathrm{~g}^{-1}$ olan TMA-N değerinin 12 gün sonunda $4.11 \mathrm{mg} 100 \mathrm{~g}^{-1}$ 'a arttığ tespit edilmiştir (İnanlı et al 2011). Sonuçlar genel olarak bulgularımızla benzerlik göstermektedir.

\section{Çizelge 3- Hamsi döner örneklerindeki pH, TVB-N, TBA ve TMA-N değerindeki değişimler ${ }^{*},(\mathrm{x} \pm \mathbf{S H})^{* *}$}

Table 3- Changes of the $\mathrm{pH}, T V B-N, T B A$ ve TMA-N values in anchovy döner samples* ${ }^{*}(x \pm S E)^{* *}$

\begin{tabular}{lllll}
\hline$G \ddot{u n}$ & $p H$ & $T B A, m g M D A g^{-l}$ & $T V B-N, m g 100 g^{-1}$ & $T M A-N, m g 100 g^{-1}$ \\
\hline Ç & $6.61 \pm 0.01^{\mathrm{a}}$ & $1.01 \pm 0.03^{\mathrm{ef}}$ & $10.67 \pm 0.36^{\mathrm{e}}$ & $0.84 \pm 0.12^{\mathrm{e}}$ \\
$\mathrm{M}$ & $6.29 \pm 0^{\mathrm{e}}$ & $0.79 \pm 0.05^{\mathrm{f}}$ & $11.17 \pm 0.44^{\mathrm{e}}$ & $0.62 \pm 0^{\mathrm{e}}$ \\
1 & $6.40 \pm 0.03^{\mathrm{d}}$ & $1.13 \pm 0.02^{\mathrm{e}}$ & $28.40 \pm 0.22^{\mathrm{d}}$ & $4.22 \pm 0.06^{\mathrm{d}}$ \\
7 & $6.48 \pm 0.02^{\mathrm{bcd}}$ & $1.91 \pm 0.01^{\mathrm{d}}$ & $31.34 \pm 0.50^{\mathrm{bc}}$ & $4.36 \pm 0.11^{\mathrm{d}}$ \\
14 & $6.54 \pm 0.02^{\mathrm{ab}}$ & $1.86 \pm 0.05^{\mathrm{d}}$ & $31.68 \pm 0.88^{\mathrm{bc}}$ & $4.46 \pm 0.07^{\mathrm{cd}}$ \\
21 & $6.52 \pm 0.06^{\mathrm{abc}}$ & $2.39 \pm 0.18^{\mathrm{bc}}$ & $32.94 \pm 0.88^{\mathrm{ab}}$ & $4.22 \pm 0.15^{\mathrm{d}}$ \\
28 & $6.43 \pm 0.01^{\mathrm{cd}}$ & $2.43 \pm 0.06^{\mathrm{bc}}$ & $31.59 \pm 0.67^{\mathrm{bc}}$ & $4.57 \pm 0,19^{\mathrm{bcd}}$ \\
35 & $6.51 \pm 0.02^{\mathrm{bc}}$ & $2.25 \pm 0.07^{\mathrm{c}}$ & $31.42 \pm 0.30^{\mathrm{bc}}$ & $4.71 \pm 0.09^{\mathrm{bcd}}$ \\
42 & $6.43 \pm 0.02^{\mathrm{cd}}$ & $2.54 \pm 0.05^{\mathrm{bc}}$ & $30.58 \pm 0.22^{\mathrm{bc}}$ & $4.87 \pm 0.25^{\mathrm{abc}}$ \\
49 & $6.45 \pm 0.03^{\mathrm{bcd}}$ & $2.68 \pm 0.09^{\mathrm{b}}$ & $31.76 \pm 0.14^{\mathrm{bc}}$ & $4.70 \pm 0.20^{\mathrm{bcd}}$ \\
56 & $6.30 \pm 0.02^{\mathrm{e}}$ & $2.63 \pm 0.12^{\mathrm{b}}$ & $32.18 \pm 0.36^{\mathrm{bc}}$ & $4.96 \pm 0.05^{\mathrm{ab}}$ \\
63 & $6.25 \pm 0.03^{\mathrm{e}}$ & $3.53 \pm 0.21^{\mathrm{a}}$ & $34.03 \pm 0.66^{\mathrm{a}}$ & $5.25 \pm 0.25^{\mathrm{a}}$ \\
\hline
\end{tabular}

", aynı sütunda farklı harfler bulunduran değerler arasında istatistiki fark önemlidir $(\mathrm{P}<0.05) ;{ }^{* *}$, ortalama \pm standart hata; Ç, çiğ hamsi; $\mathrm{M}$, marine hamsi 
Su ürünlerinin tüketilebilirliğinin belirlenmesinde kullanılan yöntemlerden biri de mikrobiyolojik analizlerdir. Aerobik bakteri sayısı için limit değer 7 logkob g-1 olarak bildirilmiştir (ICMSF 1986). $\mathrm{Bu}$ çalışmada, başlangıçta çiğ hamside maya-küf tespit edilmemiş olup, TMAB, TPAB ve koliform için sırasıyla 5.56 logkob g-1, $3.61 \operatorname{logkob~g^{-1}}$ ve 1.87 logkob g ${ }^{-1}$ olarak saptanmıştır. Döner yapımı ile uygulanan 1 sıl işlemle TMAB sayısı 3.17 logkob $\mathrm{g}^{-1}$ 'a düşerken TPAB ve koliform tespit edilememiştir. Ancak depolama süreci içerisinde koliform ve maya-küf dışında artış gösterdiği ve limit değerlere ulaşmadığ görülmüştür (Çizelge 4). Hamsiden kek üretimi ile ilgili bir araştırmada, hamsi filetolarında TMAB sayıs1 2.30 logkob $\mathrm{g}^{-1}$,
TPAB sayıs1 3.36 logkob $\mathrm{g}^{-1}$ ve maya-küf sayıs1 da 3.28 logkob $\mathrm{g}^{-1}$ olarak belirlenmiş olup kek yapımıyla elde edilen bu değerlerde düşüş, depolama ile birlikte de tekrar artı̧̧ tespit edilmiştir (İnanlı et al 2011). Hamsi kuşlarının pişirilmesiyle birlikte mezofilik ve pisikrotrofik bakteri sayısında azalma (Köse et al 2001), farklı balık türleriyle döner yapılan araştırmada; alabalık, orkinos ve somondan yapılan döner örneklerinde $4{ }^{\circ} \mathrm{C}$ 'de 1 . günlük depolama sonrasında toplam mezofilik aerobik bakteri ve koliform sayısında çiğ balıketine göre önemli $(\mathrm{P}<0.05)$ azalma tespit edilmiştir (Şimşek 2011). Yukarıda bahsi geçen araştırma sonuçları ile çalışmamız sonuçları uyumludur.

Çizelge 4- Hamsi döner örneklerinin muhafaza süresince mikroorganizma yükü $\left(\operatorname{logkob} \mathbf{g}^{-1}\right)^{*},(\mathbf{x} \pm \mathbf{S H})^{* *}$ Table 4- Microbial load of the anchovy döner samples during storage $\left(\log c f u g^{-1}\right)^{*},(x \pm S E)^{* *}$

\begin{tabular}{lllll}
\hline Gün & $T M A B$ & $T P A B$ & Koliform & Maya-küf \\
\hline $\mathrm{C}$ & $5.56 \pm 0.04^{\mathrm{a}}$ & $3.61 \pm 0.09^{\mathrm{c}}$ & $1.87 \pm 0.03$ & $<1.0$ \\
$\mathrm{M}$ & $3.59 \pm 0.01^{\mathrm{j}}$ & $3.63 \pm 0.01^{\mathrm{bc}}$ & $<1.0$ & $<1.0$ \\
1 & $3.17 \pm 0.04^{\mathrm{k}}$ & $<1.0$ & $<1.0$ & $<1.0$ \\
7 & $4.62 \pm 0.03^{\mathrm{d}}$ & $<1.0$ & $<1.0$ & $<1.0$ \\
14 & $4.22 \pm 0.01^{\mathrm{g}}$ & $<1.0$ & $<1.0$ & $<1.0$ \\
21 & $4.39 \pm 0.01^{\mathrm{f}}$ & $2.70 \pm 0.03^{\mathrm{e}}$ & $<1.0$ & $<1.0$ \\
28 & $4.51 \pm 0.03^{\mathrm{e}}$ & $2.47 \pm 0.03^{\mathrm{f}}$ & $<1.0$ & $<1.0$ \\
35 & $4.73 \pm 0.02^{\mathrm{bc}}$ & $4.34 \pm 0.01^{\mathrm{a}}$ & $<1.0$ & $<1.0$ \\
42 & $4.65 \pm 0.03^{\mathrm{cd}}$ & $4.38 \pm 0.01^{\mathrm{a}}$ & $<1.0$ & $<1.0$ \\
49 & $3.95 \pm 0.05^{\mathrm{h}}$ & $3.48 \pm 0.01^{\mathrm{d}}$ & $<1.0$ & $<1.0$ \\
56 & $4.25 \pm 0.03^{\mathrm{g}}$ & $3.75 \pm 0.07^{\mathrm{b}}$ & $<1.0$ & $<1.0$ \\
63 & $4.82 \pm 0.03^{\mathrm{b}}$ & $4.39 \pm 0.05^{\mathrm{a}}$ & $<1.0$ & $<1.0$ \\
\hline
\end{tabular}

", aynı sütunda farklı harfler bulunduran değerler arasında istatistiki fark önemlidir $(\mathrm{P}<0.05)$; ${ }^{* *}$, ortalama \pm standart hata; $\mathrm{C}$, çiğ hamsi; $\mathrm{M}$, marine hamsi

Hamsi döner örneklerinin duyusal analiz sonuçlarına bakıldığında, panelistlerce değerlendirilen parametrelerde yüksek puanlar aldığı, muhafaza süresince bu parametreye ilişkin puanların süreyle doğru orantılı olarak azaldığı, depolamanın 63 . gününde ise tüketilemeyecek sınır değerlere ulaştı̆̆ görülmüştür (Çizelge 5). Şimşek (2011) çalışmasında alabalık, orkinos ve somon olmak üzere üç farklı balık türünden elde edilen dönerlerin panelistlerce kabul edilebilirliğinin yüksek olduğunu bildirilmiştir.
$\mathrm{Bu}$ sonuçlar çalıșmamız sonuçları ile benzerlik göstermektedir.

\section{Sonuçlar}

Çalışmada hamsi döner örneklerinin doymamış yağ asitleri, özelliklede DHA ve EPA gibi önemli çoklu doymamış yağ asitleri ve $\sum \mathrm{n} 6 / \sum \mathrm{n} 3$ oranı bakımından beslenme açısından önemli bir kaynak olabileceği düşünülmektedir. Çalışmada elde edilen bilgiler ışığında hamsi dönerinin tüketici beğenisine 
Çizelge 5- Hamsi döner örneklerinin muhafaza süresince duyusal analiz sonuçları ${ }^{*},(x \pm \mathbf{S H})^{* *}$

Table 5- Results of the sensory anaylysis of anchovy döner samples during storage ${ }^{*},(x \pm S E)^{* *}$

\begin{tabular}{llllll}
\hline Gün & Renk & Koku & Lezzet & Tekstür & Genel beğeni \\
\hline 1 & $7.50 \pm 0.23^{\mathrm{a}}$ & $8.08 \pm 0.22^{\mathrm{a}}$ & $8.33 \pm 0.14^{\mathrm{a}}$ & $7.50 \pm 0.21^{\mathrm{a}}$ & $7.91 \pm 0.15^{\mathrm{a}}$ \\
7 & $7.25 \pm 0.17^{\mathrm{a}}$ & $7.66 \pm 0.22^{\mathrm{ab}}$ & $8.16 \pm 0.20^{\mathrm{a}}$ & $7.66 \pm 0.25^{\mathrm{a}}$ & $7.91 \pm 0.14^{\mathrm{a}}$ \\
14 & $7.50 \pm 0.26^{\mathrm{a}}$ & $7.58 \pm 0.28^{\mathrm{ab}}$ & $8.00 \pm 0.17^{\mathrm{ab}}$ & $7.83 \pm 0.24^{\mathrm{a}}$ & $7.83 \pm 0.16^{\mathrm{a}}$ \\
21 & $7.08 \pm 0.19^{\mathrm{a}}$ & $7.66 \pm 0.28^{\mathrm{ab}}$ & $8.00 \pm 0.30^{\mathrm{ab}}$ & $7.75 \pm 0.25^{\mathrm{a}}$ & $7.83 \pm 0.24^{\mathrm{a}}$ \\
28 & $7.25 \pm 0.21^{\mathrm{a}}$ & $7.25 \pm 0.32^{\mathrm{bc}}$ & $7.33 \pm 0.33^{\mathrm{bc}}$ & $6.91 \pm 0.19^{\mathrm{b}}$ & $7.08 \pm 0.19^{\mathrm{b}}$ \\
35 & $6.83 \pm 0.16^{\mathrm{ab}}$ & $7.08 \pm 0.19^{\mathrm{bc}}$ & $6.66 \pm 0.18^{\mathrm{cd}}$ & $6.75 \pm 0.25^{\mathrm{b}}$ & $6.83 \pm 0.20^{\mathrm{b}}$ \\
42 & $6.33 \pm 0.22^{\mathrm{b}}$ & $6.75 \pm 0.21^{\mathrm{c}}$ & $6.25 \pm 0.27^{\mathrm{d}}$ & $6.33 \pm 0.25^{\mathrm{b}}$ & $6.50 \pm 0.26^{\mathrm{b}}$ \\
49 & $5.00 \pm 0.27^{\mathrm{c}}$ & $5.08 \pm 0.33^{\mathrm{d}}$ & $4.66 \pm 0.30^{\mathrm{e}}$ & $4.91 \pm 0.35^{\mathrm{c}}$ & $4.75 \pm 0.35^{\mathrm{c}}$ \\
56 & $4.66 \pm 0.22^{\mathrm{c}}$ & $3.83 \pm 0.16^{\mathrm{e}}$ & $3.75 \pm 0.27^{\mathrm{f}}$ & $3.58 \pm 0.28^{\mathrm{d}}$ & $3.91 \pm 0.25^{\mathrm{d}}$ \\
63 & $2.33 \pm 0.14^{\mathrm{d}}$ & $1.91 \pm 0.14^{\mathrm{f}}$ & $1.50 \pm 0.15^{\mathrm{g}}$ & $1.33 \pm 0.14^{\mathrm{e}}$ & $1.41 \pm 0.15^{\mathrm{e}}$ \\
\hline
\end{tabular}

*, aynı sütunda farklı harfler bulunduran değerler arasında istatistiki fark önemlidir $(\mathrm{P}<0.05) ;{ }^{* *}$, ortalama \pm standart hata

sahip olduğu belirlenmiştir. Hamsi dönerinin depolama süresince kimyasal ve mikrobiyolojik olarak limit değerleri aşmadığı tespit edilmiştir. Hamsi döner örneklerinin duyusal analiz sonuçlarına bakıldığında, panelistlerce değerlendirilen bütün parametrelerin yüksek puanlar aldığı, muhafaza süresince bu parametre ilişkin puanların süreyle doğru orantılı olacak biçimde azaldığı, depolamanın 63. gününde ise tüketilemeyecek sınır değerlere ulaştığı belirlenmiştir.

Su ürünleri üretimimizin en önemli türlerinden olan hamsinin alternatif işleme tekniklerinden biriyle işlenerek farklı bir lezzette sunulması, hamsinin daha çok kişi tarafından tüketilmesini destekleyecektir. Ayrıca çalışmanın benzer konularda yapılacak AR-GE çalışmaları için de teşvik edici olacağı kanısındayız.

\section{Teşekkür}

Bu çalışma Süleyman Demirel Üniversitesi Bilimsel Araştırma Projeleri Koordinasyon Birimince (P.No: 2624-M-2010) desteklenmiştir.

\section{Kaynaklar}

Akkuş Ö, Varlık C, Erkan N \& Mol S (2004). Çiğ ve haşlanmış balık etinden yapılmış köftelerin bazı kalite parametrelerinin incelenmesi. Turkish Journal of Veterinary and Animal Sciences 28: 79-85
AOAC (1998). Offical methods of analysis. Association of Offical Analytical Chemists USA.

AOAC (2000). Offical methods of analysis. Association of Offical Analytical Chemists, USA

Arslan A, Çelik C, Ateş G, Kök A \& Kaya A (1997). Vakumlu vakumsuz aynalı sazan (Cyprinus carpio L.) pastırmalarının mikrobiyolojik ve kimyasal kalitesinin incelenmesi. Turkish Journal of Veterinary and Animal Sciences 21: 23-29

Ayas D (2006). Gökkuşağı alabalığı (Oncorhyncus mykiss), hamsi (Engraulis encrasicolus) ve sardalya (Sardina pilchardus)'nın sıcak tütsülenmesi sonrasındaki kimyasal kompozisyon oranlarındaki değişimleri. Ege Üniversitesi Su Ürünleri Fakültesi Su Ürünleri Dergisi 23(1-3): 343-346

Bligh E G \& Dyer W J (1959). A rapid method of total lipid extraction and purification. Canadian Journal of Biochemistry and Physiology 37: 911-917

Cadun A, Cakli S \& Kisla D (2005). A study of marination of deepwater pink shrimp (Parapenaeus longirostris, Lucas, 1846) and its shelf life. Food Chemistry 90: 53-59

Erkan N \& Özden Ö (2008). Quality assessment of whole and gutted sardines (Sardina pilchardus) stored in ice. International Journal of Food Science and Technology 43: 1549-1559

Gökoğlu N, Özden Ö, Erkan N, Baygar T \& Metin S (1999). Seasonal variationin fat content of anchovy (Engarulis encrasicolus). International Journal of Food Science and Technology 34: 401-402 
Harrigan W F \& McCance M E (1976). Laboratory Methods In Food And Dairy Microbiolgy, London

Huss, H H (1988). Fresh Fish Quality and Quality Changes. FAO Fisheries Series No: 29, Rome

Ichihara K, Shibahara A, Yamamoto K \& Nakayama T (1996). An improved method for rapid analysis of the fatty acids of glycerolipids. Lipids 31: 535-539

ICMSF (1978). International Commission on Microbiological Specifications for Foods. Microorganism in Foods 1., 2nd ed., Toronto

ICMSF (1986). International Commission on Microbiological Specifications for Foods. Microorganism in Foods 2., 2nd ed., Toronto

İnanlı A $\mathrm{G}$, Özpolat $\mathrm{E}$, Çoban Ö $\mathrm{E} \&$ Karaton $\mathrm{N}$ (2010). Marine edilmiş hamsi balığının (Engraulis encrasicolus, L.,1758) kimyasal bileşimi ve farklı soslarda duyusal değerlendirilmesi. Journal of FisheriesSciences.com 4(4): 455-461

İnanlı A G, Karaton N \& Çoban Ö E (2011). Sensorial, chemical and microbiological quality of anchovy cake. African Journal of Biotechnology 10(48): 98709874

Kaba N (2006). The Determination of technology \& storage period of surimi production of anchovy (Engraulis encrasicholus L.,1758). Turkish Journal of Fisheries and Aquatic Sciences 6: 29-35

Karaçam H \& Düzgüneş E (1988). Hamsi (Engraulis encrasicolus, L.1758) balıklarında net et verimi ve besin analizleri üzerine bir araştırma. Ege Üniversitesi Su Ürünleri Yüksek Okulu Su Ürünleri Dergisi 5(1920): 100-107

Kaya Y \& Turan H (2010). Comparison of protein, lipid, and fatty acids composition of anchovy (Engraulis encrasicolus) during the commercial cathing season. Journal of Muscle Foods 21: 474-483

Kaya Y, Duyar H A \& Erdem M E (2004). Balık yă̆ asitlerinin insan sağlığı için önemi. Ege Üniversitesi Su Ürünleri Fakültesi Su Ürünleri Dergisi 21(3-4): 365-370

Kenar M (2009). Aromatik bitkilerden elde edilen doğal antioksidanların balık filetosu üzerindeki duyusal, kimyasal ve mikrobiyolojik etkilerinin incelenmesi, Yüksek lisans tezi, Çukurova Üniversitesi Fen Bilimleri Enstitüsü (Basılmamış), Adana

Kocatepe D \& Turan H (2012). Proximate and fatty acid composition of some commercially inportant fish species from the Sinop Region of the Black Sea. Lipids 47: 635-641

Kolsarıcı N \& Özkaya Ö (1998). Gökkuşağı alabalığ (Salmo gairdneri)'nın raf ömrü üzerine tütsüleme yöntemleri ve depolama sıcaklığının etkisi. Turkish Journal of Veterinary and Animal Sciences 22: 273284

Köse S \& Erdem M E (2004). An Investigation of quality changes in anchovy (Egraulis encrasicolus, L.,1758) stored at different temperatures. Turkish Journal of Veterinary and Animal Sciences 28: 575-582

Köse S, Karaçam H, Kutlu S \& Boran M (2001). Investigating the shelf-life of the anchovy dish called 'Hamsikuşu' in frozen storage at $-18 \pm 1{ }^{\circ} \mathrm{C}$. Turkish Journal of Veterinary and Animal Sciences 25: 651656

Lovell R T (1975). Laboratory Manual for Fish Feed Analysis and Fish Nutrition Studies. Auburn, Alabama

Lovell R T (1981). Laboratory Manual for Fish Feed Analysis and Fish Nutrition Studies, Auburn, Alabama

Moreira A B, Visentainer J V, de Souza N E \& Matsushita M (2001). Fatty acids profile and cholesterol contents of three Brazilian Brycon freshwater fishes. Journal of Food Composition and Analysis 14: 565-574

Nicholas T A (2003). Antimicrobial use of native and enzymatically degraded chitosans for seafood aplications. The University of Maine, MSc Thesis, Maine

Olgunoğlu İ A (2007). Marine edilmiş hamside (Engraulis ancrasicholus L.,1758) duyusal kimyasal ve mikrobiyolojik değişimler. Doktora tezi, Çukurova Üniversitesi Fen Bilimleri Enstitüsü (Basılmamış), Adana

Öksüz A \& Özyılmaz A (2010). Changes in fatty acid compositions of Black Sea anchovy (Engraulis encrasicolus L.1758) during cathing season. Turkish Journal of Fisheries and Aqutic Sciences 10: 381-385

Özden Ö (2005). Changes in amino acid and fatty acid composition during shelf-life of marinated fish. Journal of the Science Food and Agriculture 85: 2015-2020

Refai M K (1979). Manual of Food Quality Control, 4. Microbiology Analysis, Food and Agriculture Organization of the United Nation, Rome

Ruiz-Capillas C \& Moral A (2001). Correlation between biochemical and sensory quality indices in hake stored in ice. Food Research International 34: 441-447 
Şimşek A (2011). Tüketime hazır balık döner üretimi; kimyasal, mikrobiyolojik ve duyusal özelliklerinin araştırılması, Yüksek lisans tezi, SDÜ Fen Bilimleri Enstitüsü (Basılmamış), Isparta

Tanakol R, Yazıcı Z, Şener E \& Sencer E (1999). Fatty acid composition of 19 species fish from the Black Sea and the Marmara Sea. Lipids 34: 291-297

Taşkaya L, Çaklı Ş, Kışla D \& Kılınç B (2003). Qualitiy changes of fish burger from rainbow trout during refrigrated storage. Ege Üniversitesi Su Ürünleri Fakültesi Su Ürünleri Dergisi 20(1-2): 147-154

Tokur B, Özkütük S, Atıcı E, Özyurt G \& Özyurt C E (2006). Chemical and sensory quality changesof fish fingers, made from mirror carp (Cyprinus carpio L., 1758) during frozen storage $\left(-18^{\circ} \mathrm{C}\right)$. Food Chemistry 99: $335-341$

Tufan B, Koral S \& Köse S (2011). Changes during fishing season in the fat content and fatty acid profile of edible muscle, liver and gonads of anchovy (Engraulis encrasicolus) caugth in the Turkish Black Sea. International Journal of Food Science and Technology 46: 800-810
Turan H, Kaya Y \& Sönmez G (2006). Balık etinin besin değeri ve insan sağlığındaki yeri. Ege Üniversitesi $S u$ Ürünleri Fakültesi Su Ürünleri Dergisi 23(1-3): 505508

TÜİK (2013). Su Ürünleri İstatistikleri, Yayın No: 4349, Ankara

Varlık C, Uğur M, Gökoğlu N \& Gün H (1993). Su Ürünlerinde Kalite Kontrol İlke ve Yöntemleri. Gida Teknolojisi Derneği Yayın No: 17, Ankara

Varlık C, Erkan N, Metin S, Baygar T \& Özden Ö (2000). Marine balık köftesinin raf ömrünün belirlenmesi. Turkish Journal of Veterinary and Animal Sciences 24: 593-597

Varlık C, Özden Ö, Erkan N \& Alakavuk D Ü (2007). $\mathrm{Su}$ Ürünlerinde Temel Kalite Kontrol. İstanbul Üniversitesi Yayın No: 4662, İstanbul

Zlatanos S \& Laskaridis K (2007). Seasonal variation in the fatty acids composition of three mediterranean fish sardine (Sardina pilchardus), anchovy (Engraulis encrasicolus) and picarel (Spicara smaris). Food Chemistry 103: 725-728 